\title{
Correction to: Wonderland in winter and little Europe in summer: a case study on how Harbin promotes its international image
}

\author{
Sining Kong ${ }^{1} \cdot$ Huan Chen ${ }^{1}$
}

Published online: 23 November 2018

(c) Springer Nature Limited 2018 Correction to: Place Brand Public Dipl (2018) 14:272-284
https://doi.org/10.1057/s41254-017-0086-2

The university name in the authors' affiliation was incorrect in the published article. The correct affiliation should read as:
1. College of Journalism and Communications, University of Florida, PO Box 118400, Gainesville, FL 32603, USA

The original article can be found online at https:// doi.org/10.1057/s41254-017-0086-2.

Sining Kong

kongsn@ufl.edu

1 College of Journalism and Communications, University of Florida, PO Box 118400, Gainesville, FL 32603, USA 